\title{
British Journal of Occupational Therapy: 80 years of reflecting and influencing occupational therapy
}

The first issue of the British Journal of Occupational Therapy was published in 1938. This year is the celebration of its 80th anniversary which provides an opportunity to consider how it has reflected and influenced the profession. The world of occupational therapy was very different in 1938 and the journal of the time reflected that.

The origins of the profession in the United Kingdom (UK) began in 1922 with the employment of an 'occupational instructor' at Gartnavel Royal Mental Hospital in Glasgow. Three years later the first person to receive a formal education as an occupational therapist in the USA returned to Scotland to work. The initial school of occupational therapy was founded in 1930. By 1938, occupational therapy was a very small profession and the journal acted as a link between members providing information about the developing professional organisation, accounts of meetings, book reviews and social information about members.

Initially, the journal was published two or three times a year with each issue having a few pages. Later, as more material became available it moved to four issues a year and in1957 it adopted its current format of a monthly publication. At that time it also included educational articles usually written by doctors and a correspondence column to encourage exchange of ideas and information.

Research articles began to feature in the journal during the 1960s and 1970s. These were often small scale, local projects and at the same time there were reports explaining the need for more research in the profession and encouraging occupational therapists to become involved in research. By the 1980s research articles increased and the 1990s saw the introduction of degree qualifications for all occupational therapists in the UK. As these degree programmes included education about research methods, new generations of occupational therapists had a basic understanding of research, thus enabling individual therapists to develop their research qualifications and the profession to build research capacity.

The journal has continued to flourish with many significant achievements in the last few years - gaining an Impact Factor, developing an International Editorial Board, appointing an Editor-in-Chief and moving to an online journal published by Sage.

Today, it is an international journal publishing mainly research and review articles from many counties. In 2017 we published authors from 17 countries. We are aware of the challenges facing readers whose first language is not English and earlier this year we published an editorial by a Japanese author, who is a member of our Editorial Board, in both English and Japanese (NAKAMURA-THOMAS, 2018). Like all our editorials, it is free to read and we hope to expand dual language editorials to other languages.

The journal has maintained and strengthened its focus on publishing research articles and reviews that advance knowledge and provide the evidence for practice. We are committed to publishing pilot and feasibility studies and Drummond (2017) in her editorial explained their value in testing the basis for future larger studies. However, they can be difficult for researchers to publish as they are often small scale and may not show definite conclusions. To emphasize them, they are included in a regular issue and also in an online Spotlight Collection. In one recent example Eakman et al. (2017) found that it was feasible to deliver a controlled trial of a multi-component CBT-I intervention delivered by occupational therapists to injured veterans with chronic insomnia. In another editorial, Unsworth (2017) explained the importance of rigorous review articles to search for and synthesis the findings from a number of research studies focusing on a topic or answering a specific question. This had already resulted in an increase in the number reviews submitted and more are welcomed.

Reflecting the broad scope of international occupational therapy practice, the research now published in the journal relates to different life stages and conditions. In one of the most downloaded articles, Allen 
and Casey (2017) examined data on 93 children, between the ages of 5 to 12 years, with developmental coordination disorder. They found that most of them had some difficulties in sensory processing and integration that influenced their participation in everyday activities. These difficulties differed significantly between those with co-morbid autistic spectrum disorder and those without. Prior et al. (2017) explored the views of 32 people with inflammatory arthritis about an occupational therapy led job retention work rehabilitation programme they received. They considered that they were able to cope better at work and valued both the emotional support and the practical self-management education in the programme. In an innovative study to enable older people living at home to be more involved in acquiring assistive devices, Spiliotopoulou, Atwal and McIntyre (2018) involved 26 older people and 25 health care professionals in establishing the accuracy of measurements of height of baths, toilets, stairs etc. The resultant guidance enables older people and health professionals to measure home items reliably and accurately.

These examples illustrate the range of articles that the journal publishes to advance knowledge and enable occupational therapists and colleagues have strong evidence to guide practice. Just as issues in previous years emphasised the need for more research, that theme remains. Now a study has identified what helps and what hinders occupational therapists to engage in research. Di Bona et al. (2017) conducted focus groups with 28 occupational therapists involved in a large scale research programme evaluating a community occupational therapy intervention for people living with mild to moderate dementia and their family carers. Their involvement was challenged by implementing research tasks and new interventions but enabled by support, allocated time and positive attitudes.

It is interesting to observe how the British Journal of Occupational Therapy has reflected the needs of the profession through the decades. From providing an educational resource and acting as a link between the small number of therapists in the early years to becoming the official academic journal of the Royal College of Occupational Therapists publishing international research to advance occupational therapy.

\section{Christine Craik}

Editor-in-Chief, British Journal of Occupational Therapy

Royal College of Occupational Therapists

\section{References}

ALLEN, S.; CASEY, J. Developmental coordination disorders and sensory processing and integration: Incidence, associations and co-morbidities. British Journal of Occupational Therapy, London, v. 80, n. 9, p. 549-557, 2017. http:// dx.doi.org/10.1177/0308022617709183.

DI BONA, L. et al. Enablers and challenges to occupational therapists' research engagement: a qualitative study. British Journal of Occupational Therapy, London, v. 80, n. 11, p. 642-650, 2017. http://dx.doi.org/10.1177/0308022617719218.

DRUMMOND, A. Feasibility and pilot studies: why are they important? British Journal of Occupational Therapy, London, v. 80, n. 6, p. 335-336, 2017. http://dx.doi.org/10.1177/0308022617697743.

EAKMAN, A. M. et al. Restoring effective sleep tranquility (REST): A feasibility and pilot study. British Journal of Occupational Therapy, London, v. 80, n. 6, p. 350-360, 2017. http://dx.doi.org/10.1177/0308022617691538.

NAKAMURA-THOMAS, H. Occupation-based practice: A new momentum in Japan. British Journal of Occupational Therapy, London, v. 81, n. 7, p. 367-368, 2018. http://dx.doi.org/10.1177/0308022617753325.

PRIOR, Y. et al. A qualitative evaluation of occupational therapy-led work rehabilitation for people with inflammatory arthritis: Patients'views. British Journal of Occupational Therapy, London, v. 80, n. 1, p. 39-48, 2017. http://dx.doi. org/10.1177/0308022616672666.

SPILIOTOPOULOU, G.; ATWAL, A.; MCINTYRE, A. The use of evidence-based guidance to enable reliable and accurate measurements of the home environment. British Journal of Occupational Therapy, London, v. 81, n. 1, p. 32-41, 2018. http://dx.doi.org/10.1177/0308022617737689.

UNSWORTH, C. Review papers: getting the best occupational therapy evidence into practice. British Journal of Occupational Therapy, London, v. 80, n. 3, p. 143-144, 2017. http://dx.doi.org/10.1177/0308022616688702. 